\title{
Potential Traffic Accident Analysis of Bangkinang - Rantau Berangin Road at Riau Province, Indonesia
}

\author{
Abdul Kudus Zaini ${ }^{1, *}$, Abdussalam ${ }^{1}$ \\ ${ }^{1}$ Civil Engineering Department Universitas Islam Riau, Jalan. H. Kaharuddin Nasution KM II Perhentian Marpoyan \\ Riau 28284, Indoneisa \\ *Corresponding Author: Abdulkuduszaini@eng.uir.ac.id
}

\section{Article history}

Received: 17.02 .2021

Revised: 10.04.2021

Accepted: 25.04.2021

DOI:10.31629/jit.v2i1.3201

\begin{abstract}
A traffic accident is an unexpected and unintentional event involving a vehicle with or without other road users, resulting in human casualties (minor injuries, serious injuries, and death) and property loss. In penel itian have taken vertebra way the segments road Bangkinang - Rantau Berangin KM 60 to KM 100 . This study aims for know se how much the level of traffic accidents in the area and for get The value of Accident Rate is Black Spot and Black Site on road Bangkinang-Rantau Berangin.The method used in this research is the Calculation Analysis method by identifying the Black Spot and Black Site based on the Accident Rate. The results of the analysis of data years $2014-2018$ indicates that the segments road Bangkinang - Rantau Berangin can be identified value Accident rate which is Black Spot is the village of Pulau Gadang - Tanjung Alai with accident rate amounted to 2,069 and also the village of Tanjung Alai - Batu Bersurat with grades Accident rate amounted to 2,069. While for Accident rate against Black Site among others, namely the segment road Tanjung Alai - Batu Bersurat with Accident rate of 0.295 followed by the village of Pulau Gadang - Tanjung Alai is 0,258 and followed the village of Kuok - Village Lereng with Accident rate 0,240. From the analysis the researchers concluded that there are three locations which are the areas rawaan traffic accidents on roads Bangkinang - namely Rantau Berangin Village Tanjung Alai - Village Batu Bersurat, the village of Pulau Gadang Tanjung Alai and villages Kuok - Village Lereng .
\end{abstract}

Keywords: accident rate, black spot, black site, road user, traffic accident

\section{Introduction}

According to the data, there were 1.2 million fatalities and up to 50 million nonfatal casualties each year (WHO, 2008). It is equal to one victim in every six seconds. In Indonesia, $61 \%$ of traffic deaths happened to motorcycle rider or passenger (WHO, 2011). Even in small towns such as Kampar regency, the involvement of motorcyclists in fatal accident was almost $100 \%$ [1]. Fatal accident leads to sorrows and causes of loss in developmental resources, particularly in low to middle-income countries [2] This tendency is also occured in maritime sector [3]. Therefore, transportation safety is a continuous challenge for transport engineer due to high public expectation $[3,4]$. Thus, the United Nations declared the 20112035 Decade of Action (DoA) of Road Safety. The similar program was launched by the Indonesian Government, i.e. the 2011-2035 National Road Safety Master Plan (RUNK) for the same reason. 
Sumatra in Provinci Riau, Indonesia makes transportation become the most priority to accelerate economic relation [5].

The vehicle numbers are growth significantly by the populations (Malkamah, Siti, et.all : 1994).. Unfortunately, the growth is not balanced by the development of transportation facilities which results in traffic jam and accident. As time goes by, the number of accidents in Kampar regency is increased. This study aimed to find out the level of traffic accidents, the accident rate value (Black Spot and Black Site) of Bangkinang - Rantau Berangin, and the solutions.

\section{Theoretical Background}

Matson (1985) stated that traffic accident loss can be classified namely fatal injuries, non-fatal injuries, and material damages. Then, it can be classified based on location namely rural and urban. Pignataro (1973) stated that accident is resulted by the combination of both drivers and pedestrians behavior, extreme weather and bad vision. Hambuger (1978) stated that accident is a traffic movement due to an error in the traffic system, whether the driver (human), vehicle, road, and the environment. An error can be measured as nonconformity of conduct or regulations [4,5].

Others founded that traffic accident can be happened by three factors: (a) humans (b) vehicles (c) encvironment [5]. Based on Law Number 22 of 2009, traffic accident is an unexpected and not intentional event caused by vehicles with or without other road users resulting in human casualties and/or property loss. Traffic accident is an incident on road traffic caused by a vehicle leading to injury, damage or loss to its owner or victim [6]. Technically, traffic accident can be defined as an event caused by many factors accidentally occurred based on Random Multy Factor Event [6,7].

\section{Traffic Accident Factors}

Traffic accident is mostly caused by sleepy drivers, as reported elsewhere [6]. It is likely be the cause of more than 20 to 30 percent of traffic accidents. Furthermore, driving fatigue has a major influence as a cause of traffic accident caused by drivers [6,7]. Other results also stated that the wide range of human behavior involved in motorcyclists leads to the urgent importance of human factor in road safety [8].

Furthermore, it is stated that the traffic accident reporting system is crucial for analyzing and preventing traffic accident in terms of engineering, education, and regulations. Traffic accident report should be made for all types involving death, injury or material loss. The causes of traffic accidents may also can be analyzed based on the multicasual approach which considers three factors namely human, vehicle, road/environment [9-11]. Oder stated that traffic accident can be a result of conflict between the driver and the environment, where the driver takes action to avoid an obstacle so that it is likely to cause traffic accident. Based on several studies, it can be concluded that traffic accidents are influenced human, vehicle, and road environment, as well as the interaction and combination of two or more of the factors mentioned above $[12,13]$.

\subsection{Traffic accident-prone areas}

Black spot is an accident-prone point which can be seen from the accident data in a year. Black spot is usually associated with urban area where it can be identified with certainty and remains at a certain point [14]. Black site is an accident-prone section (road). Black site is usually found on roads outside the city where at certain ranges in this section often occur accidents. The black site range is usually more than 300 meters $[14,15]$.

\subsection{Accident rate per kilometer}

Based on the road segment, the accident rate per kilometers may formulated by the equation 1 below [16].

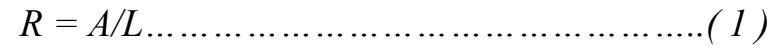

where :

$\mathrm{R}=$ Accident rate per kilometer every year

$\mathrm{A}=$ Total accident in a year.

$\mathrm{L}=$ Length of road by kilometers $(\mathrm{km})$.

\subsection{Accident rate based on vehicles trip}

$$
R=\frac{C \times 1.000 .000}{V}
$$


where :

$\mathrm{R}=$ Accident rate per 1.000 .000 vehicles $/ \mathrm{km}$

$\mathrm{C}=$ Total accident in a year

$\mathrm{V}=$ Vehicles trip in a year

\subsection{Accident rate based on the road spot}

$$
T K L=\frac{J K L \times 1.000 .000}{V \times 365}
$$

where:

$\mathrm{TKL}=$ Accident rate

$\mathrm{JKL}=$ Years of observation

$\mathrm{V} \quad=$ Traffic volume

\subsection{Black site based on accident rate on road}

$T K R=\frac{\mathrm{JKL} \times 1.000 .000}{\mathrm{~K} \times 365}$

where:

$\mathrm{TKR}=$ accident rate (in a million vehicles)

$\mathrm{K}=$ Volume $\mathrm{x}$ length of road

$\mathrm{V}=$ Traffic volume

$\mathrm{L}=$ Length of road

\subsection{Accident Rate Identification of Black Spot and Black Site}

a. Black Spot is a potential traffic accident points observed at the location (village/place) where the accident occurred. Black spot has basic criteria, if accident rate probability is more than 0.736 , it indicates high potential area $[14,15]$

b. Black Site is a potential traffic accident points observed at the road where the accident occurred. Black site has basic criteria, if accident rate probability is more than 0.003 , it indicates high potential area $[14,15]$.

\section{Results and Discussions}

Data of the traffic accident between the interest years (2014 to 2018), value of the total traffic accident, as well as traffic accident at the blackspot is presented on Table 1 to Table 3 below.

\subsection{Traffic Accident data}

Table 1. Frequency of traffic accident between 2014-2018

\begin{tabular}{|c|c|c|c|c|c|c|c|c|}
\hline \multirow[b]{2}{*}{$N_{0}$} & \multirow[b]{2}{*}{ Village } & \multirow[b]{2}{*}{ KM } & \multicolumn{5}{|c|}{ Year } & \multirow{2}{*}{$\begin{array}{l}\text { Accident } \\
\text { Frequency }\end{array}$} \\
\hline & & & 2014 & 2015 & 2016 & 2017 & 2018 & \\
\hline 1 & Bangkinang - Salo & $60-63$ & 3 & 2 & 0 & 0 & 0 & 5 \\
\hline 2 & D. Salo-D. Kuok & $63-69$ & 0 & 3 & 2 & 1 & 2 & 8 \\
\hline 3 & Kuok-D. Lereng & $69-76$ & 2 & 3 & 1 & 1 & 6 & 13 \\
\hline 4 & Lereng - Merangin & $76-80$ & 0 & 2 & 1 & 0 & 1 & 4 \\
\hline 5 & Merangin - Pulau gadang & $80-85$ & 0 & 3 & 0 & 1 & 0 & 4 \\
\hline 6 & $\begin{array}{l}\text { Pulau gadang - Tanjung } \\
\text { alai }\end{array}$ & $85-93$ & 0 & 6 & 4 & 5 & 1 & 16 \\
\hline 7 & $\begin{array}{l}\text { Tanjung alai - Batu } \\
\text { bersurat }\end{array}$ & $93-100$ & 1 & 6 & 3 & 4 & 2 & 16 \\
\hline & Jumlah & & 6 & 25 & 11 & 12 & 12 & 66 \\
\hline
\end{tabular}

In five recent years, Pulau Gadang - Tanjung Alai and Tanjung Alai - Batu Bersurat had 16 accidents, followed by Kuok - Lereng with 13 accidents, then Salo - Kuok with 8 accidents. This indicated a high number of traffic accident on the Bangkinang Rantau Berangin road of Kampar Regency.

Table 2. The value of total traffic accident between 2014 to 2018

\begin{tabular}{|c|c|c|c|c|c|c|}
\hline \multirow[t]{2}{*}{$\mathrm{N}_{0}$} & \multirow[t]{2}{*}{ SEGMENT } & \multicolumn{2}{|c|}{$\begin{array}{c}\text { ACCIDENT } \\
\text { FREQUENCY }\end{array}$} & \multirow{2}{*}{$\begin{array}{r}\text { LHR } \\
\text { (SMP) }\end{array}$} & \multirow{2}{*}{$\begin{array}{c}\text { LENGTH } \\
\text { OF } \\
\text { ROAD(KM) }\end{array}$} & \multirow{2}{*}{$\begin{array}{l}\text { ACCIDE } \\
\text { NT RAT }\end{array}$} \\
\hline & & TOTAL & RATE & & & \\
\hline 1 & Bangkinang - D. Salo & 5 & 1 & 4237 & 3 & 0,215 \\
\hline 2 & D. Salo-D. Kuok & 8 & 1,6 & 4237 & 6 & 0,172 \\
\hline 3 & D. Kuok - D. Lereng & 13 & 2,6 & 4237 & 7 & 0,240 \\
\hline 4 & D. Lereng-Merangin & 4 & 0,8 & 4237 & 4 & 0,129 \\
\hline 5 & D. Merangin - Pulau gadang & 4 & 0,8 & 4237 & 5 & 0,103 \\
\hline 6 & Pulau gadang - Tanjung Alai & 16 & 3,2 & 4237 & 8 & 0,258 \\
\hline 7 & Tanjung Alai - Batu Besurat & 16 & 3,2 & 4237 & 7 & 0,295 \\
\hline
\end{tabular}

The highest accident rate of black spot area was found in Pulau Gadang -Tanjung Alai with 0.295 accident rate, Tanjung Alai - Batu Bersurat with 0.258 accident rate, Kuok - Lereng with 0.129 accident rate, and Salo - Kuok with 0.240 accident rate. The black spot of Salo - Kuok was on 63-69 
km, Kuok - Lereng on $69-76$ km, Pulau Gadang Tanjung Alai on $85-93 \mathrm{~km}$, and Tanjung Alai Batu Bersurat on $93-100 \mathrm{~km}$.

The above table showed that the Tanjung Alai Batu had the higehst accident rate of 0.295 , then Pulau Gadang - Tanjung Alai of 0.258 , and then Kuok - Lereng of 0.240 .

Table 3. The Accident Rates of Blackspot on Bangkinang-Rantau Berangin road. (2014-2018)

\begin{tabular}{|c|c|c|c|c|c|c|}
\hline \multirow[t]{2}{*}{ No } & \multirow[t]{2}{*}{ KM } & \multirow[t]{2}{*}{ SEGMENT } & \multicolumn{2}{|c|}{$\begin{array}{c}\text { ACCIDENT } \\
\text { FREQUENCY }\end{array}$} & \multirow[t]{2}{*}{ LHR } & \multirow{2}{*}{$\begin{array}{c}\text { Accident } \\
\text { Rate }\end{array}$} \\
\hline & & & TOTAL & RATE & & \\
\hline 1 & $60-63$ & Bangkinang - Salo & 5 & 1 & 4237 & 0,646 \\
\hline 2 & $63-69$ & D. Salo-D. Kuok & 8 & 1,6 & 4237 & 1,034 \\
\hline 3 & $69-76$ & D. Kuok - D. Lereng & 13 & 2,6 & 4237 & 1,681 \\
\hline 4 & $76-80$ & D. Lereng - D. Merangin & 4 & 0,8 & 4237 & 0,517 \\
\hline 5 & $80-85$ & D. Merangin - Pulau Gadang & 4 & 0,8 & 4237 & 0,517 \\
\hline 6 & $85-93$ & Pulau Gadang - Tanjung Alai & 16 & 3,2 & 4237 & 2,069 \\
\hline 7 & $93-100$ & Tanjung Alai - Batu Besurat & 16 & 3,2 & 4237 & 2,069 \\
\hline
\end{tabular}

Based on the above table, the base value of accident rate is used standard provision namely 0.736. Thus, it can be said that at one point on the road, the level of traffic accident is high. Pulau Gadang - Tanjung Alai and Tanjung Alai - Batu Bersurat had 2.069 accident rate, followed by Kuok - Lereng village with 1.681 accident rate, and Salo Kuok with 1.034 accident rate. So it can be said that the black spots of Salo - Kuok was on $63-69 \mathrm{~km}$, Kuok - Lereng on 69 - 76 km, Pulau Gadang Tanjung Alai on $85-93 \mathrm{~km}$, and Tanjung Alai Batu Bersurat on $93-100 \mathrm{~km}$.

\subsection{Traffic accident-prone areas}

Based on the analysis, it can be resume as in the following description of the accident areas:

a. Straight Road Based on the condition requirements of Bangkinang - Rantau Berangin road section with the class I arterial road type, the researchers conducted field observation. It was found that the road width is 6 meters, which is still less than the minimum requirement of 7 meters from the left and right side. Based on the geometric point of view, the road is below standard which can cause an accident.

b. Settlement and market at Around the neighborhood, there are places of worship and markets. During peak hours from morning to evening, there are community activities which cause crowds and congestion in the area. The crowded situation makes the area has a higher frequency of traffic accident. The crowded situation can cause traffic accident from the driver and the environment, which oftenly caused by passengers get off in the area. The habit of motorcyclists stopping in this area is not paying attention to traffic sign. Objects or vehicles that suddenly stop will disturb the speed of other vehicles causing traffic accidents in the area.

Fig. 1 to Fig. 7 presented the actual condition of the road.
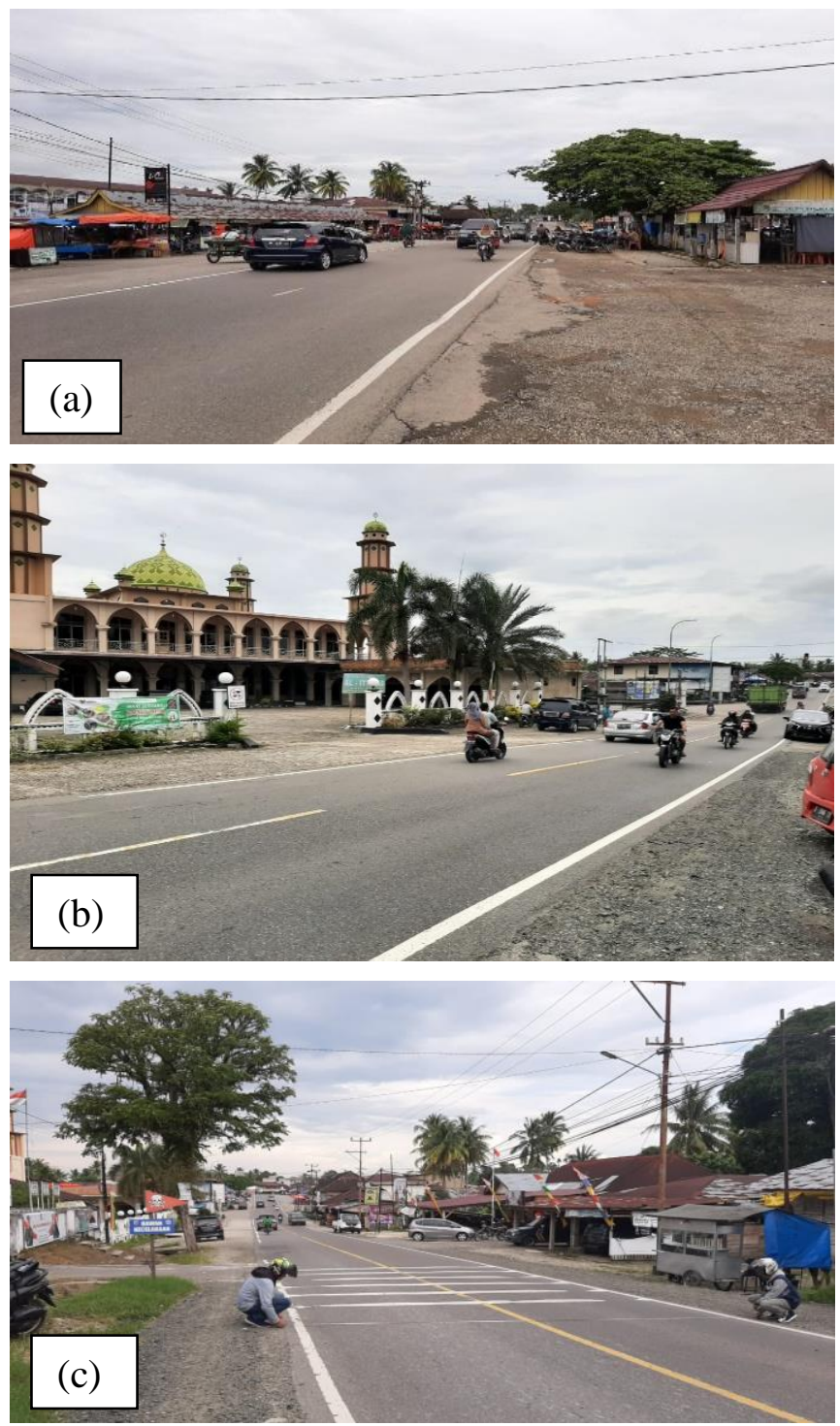

Figure 1. The area of potential traffic accident in the Km 69 of Kuok Village 


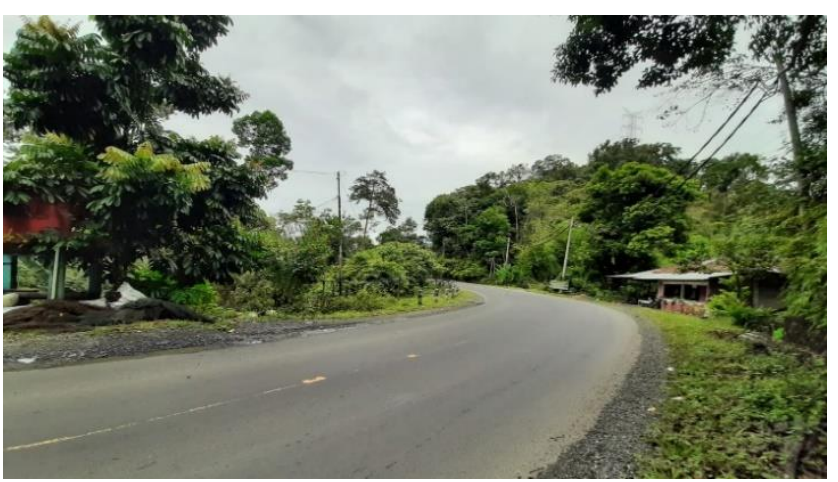

Figure 2. The pavement road of potential traffic accident in $\mathrm{Km} 71$ Kuok Village
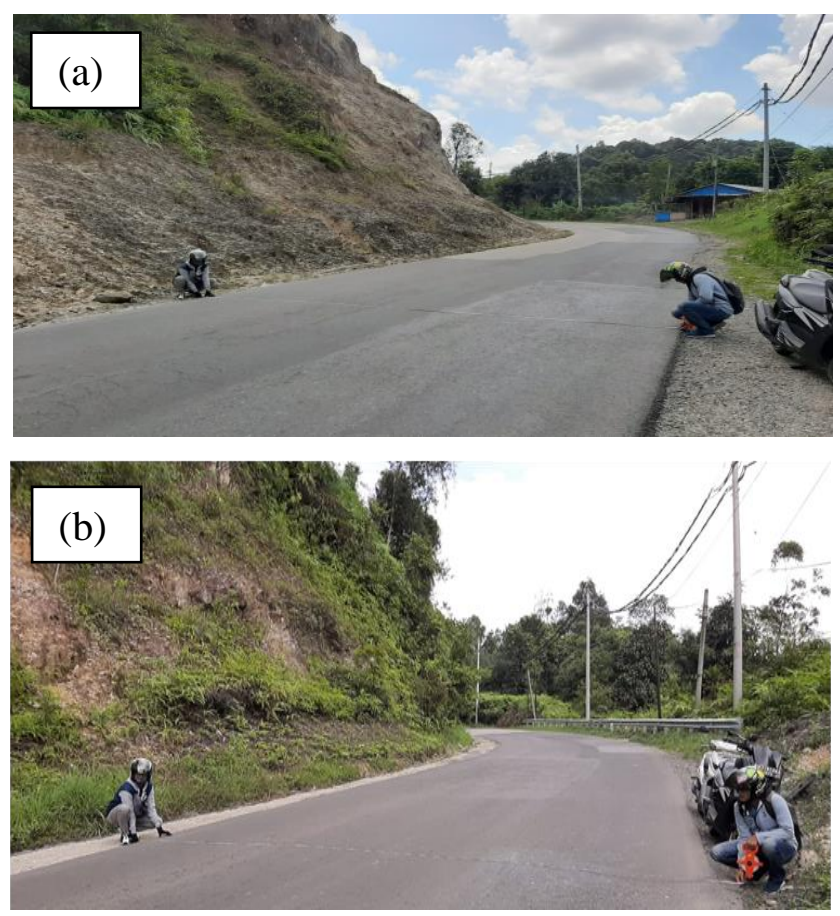

Figure 3. The pavement road of potential traffic accident in $\mathrm{Km} 78$ at Lereng Village

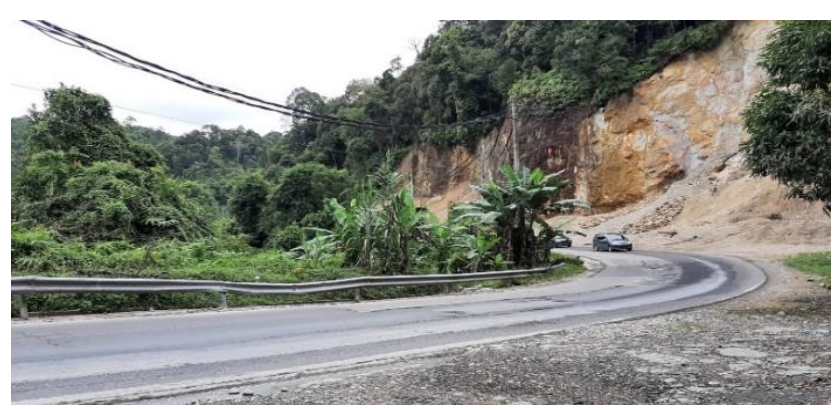

Figure 4. The pavement road of potential traffic accident in $\mathrm{Km} 81$ at Merangin Village

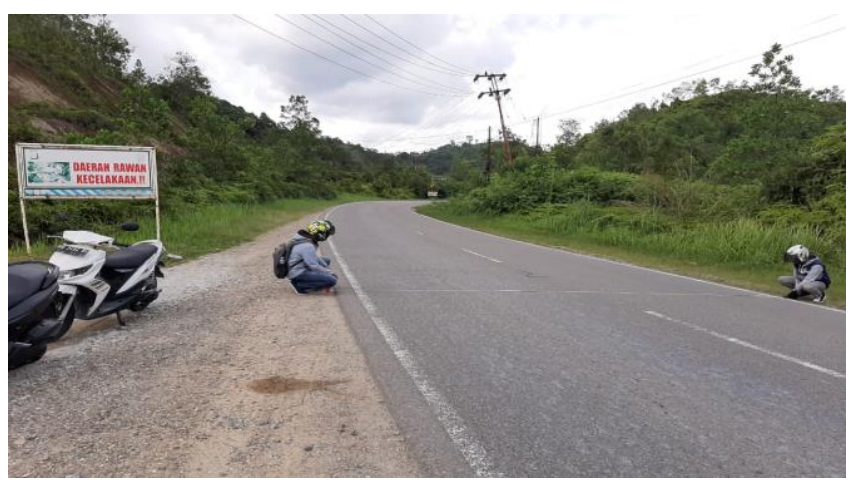

Figure 5. The pavement road of potential traffic accident in Km 92 Merangin Village

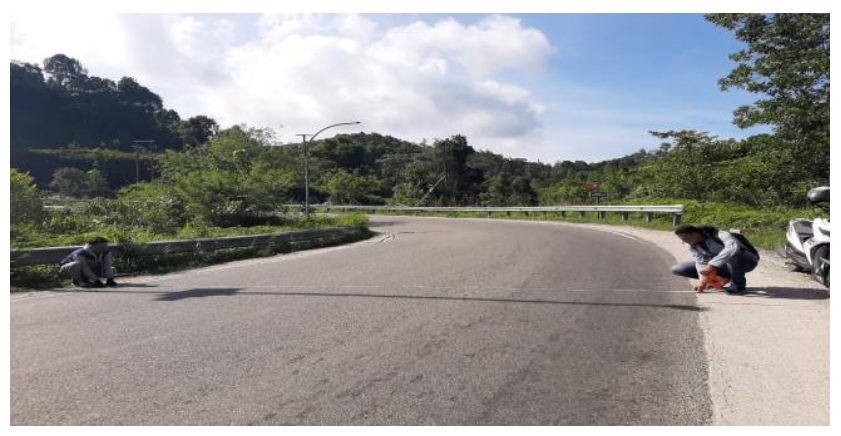

Figure 6. The area of Potential traffic accident in Kilometer 92 Tanjung Alai Batu Bersurat

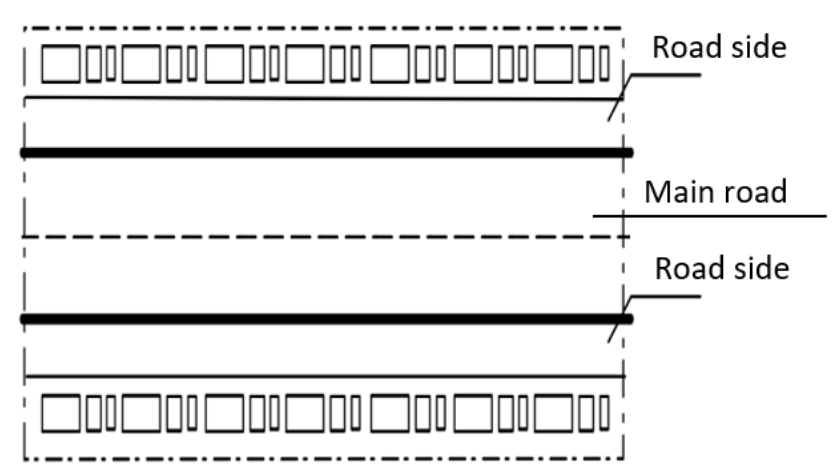

(a)

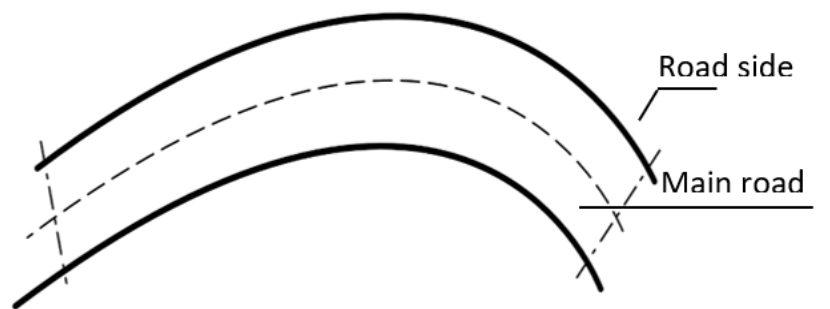

(b)

Figure 7. The general sketch area the straight (a) and the turn (b) road types 


\subsection{Prevention and management of the traffic accident}

The proposal of the prevention and management of the traffic accident are including:

a. Observing for traffic sign lighting, especially at accident-prone areas.

b. Installing traffic signs, road markings/zebra cross/and city arrangement as well as the road widening to meet the determined standards and speed limits in accident-prone areas.

c. Installing safety fences and safety mirrors for road grades.

d. Good cooperation with agencies related to traffic problems

e. If the road is damaged or has holes in it, it should be repaired by the relevant agency so that the trip becomes safer and more comfortable to avoid accidents.

f. On straight and grade roads, to reduce traffic accidents, it can be installed using speed limit signs, delineators, and if necessary, safety mirrors.

\subsection{Education}

a. Providing counseling to the people in Kampar Regency through mass media such as radio, billboards and so on.

b. Making and installing banners to students and all levels of society.

c. Making and installing banners to students and all levels of society.

\subsection{The Influence of traffic polices}

For authorized officers who are in the jurisdiction of the Kampar Police to always control the space and take action against motorcyclists who violate existing traffic laws and take strict and wise sanctions in accordance with existing regulations so as to create an orderly, safe, comfortable and in control traffic.

\section{Conclusions}

Based on the analysis, the level of traffic accidents on the Bangkinang - Rantau Berangin road was still high due to increasing number every year. Based on the accident rate value, it can be said that the level of traffic accident potential was high at a point or place where an accident occurs. A road segment can be said to be prone to having an accident Rate criterion of more than (0.003), so that the Bangkinang - Rantau Berangin road is prone to traffic accidents. At the area of Bangkinang - Rantau Berangin road, from seven areas, there were four accident-prone areas based on the black spot namely Pulau Gadang - Tanjung Alai and Tanjung Alai Batu Bersurat with 2.069 accident rate, Kuok - Slope with 1.681 accident rate, and Salo - Kuok with 1.034 accident rate. Meanwhile, the accident rate based on the black site namely Tanjung Alai - Batu Besurat with 0.295 accident rate, followed by Pulau Gadang - Tanjung Alai of 0.258 and Kuok - Lereng of 0.240. Based on this study, as an input to the government and society to reduce or prevent traffic accident namely by paying more attention to traffic signs and obeying the rules so that the accident does not occur. For further study, the researcher recommended to study road characteristics and traffic accident solutions for the Bangkinang - Rantau Berangin road of Kampar Regency.

\section{References}

[1] Da Costa, D. G. N. 2012. Accident Risk Analysis of Motorcyclist. In 15th International Symposium of the Indonesian Inter University Transport Studies Forum (pp. 1-11). Bekasi, Jakarta: FSTPT.

[2] Bliss T and Breen J. 2009. Country guideline for the conduct of road safety management capacity reviews and the specification of lead agency reforms, investment strategies and safe system projects. Implementating the recommendation of the World Report on road traffic injury prevebtion. The World Bank Global Road Safety Facility

[3] Banks J.H. 2004. Introduction to Transportation Engineering-International Edition. 2nd Edition. McGraw Hill Serries in Transportation. New York

[4] Data Perkembangan Kecelakaan Lalu Lintas Kabupaten Kampar tahun 2014-2018,

[5] Diwirjo, R 1992, “Aspek keselamatan lalu lintas dalam rangka efisiensi transportasi"

[6] Hullbert. 1981, Effect of driver fatigue (ed) "Human Factor in Highway Traffic Safety Research" Michigan State University East Lan

[7] Fahrurozzy,H, ( 1997 ) Keselamatan Lalu Lintas, Program Pasca sarana MSTT UGM, Jokjakarta

[8] Homburger, cartel, 1978, Introduction to 
transportation Engginering Reston Publishing Compani inc, Virginia USA

[9] Matson, T, M, et 1985 "Traffic Engineering MC grawhill"

[10] Malkamah, Siti, et.all,’Daerah Rawan Kecelakaan Lalu Lintas dan Upaya Mengatasi di Ujung Pandang", 1994, Yogyakarta : Universitas Gadjah Mada

[11] Pignataro, 1973. "Traffic Engineering Category Practice Entichal, in englood clifs". New Jersey, USA.

[12] Priyanto, Sigit, Transportasi Keselamatan Lalu Lintas, Yogyakarta : Program Pasca Sarjana MSTT UGM, 1997 Seminar, dan bahan kuliah.
[13] Siswoyo, B. 2016. Public perception of safety equipment marine vessel andferry in the province Maluku. Warta Penelitian Perhubungan, 28(2), pp. 147-157.

[14] Surparma budi,A, Daerah Rawan Kecelakaan Lalu lintas ruas jalan gianjar Lungkung-Ampla pura, kabupaten kubu tambahan Propinsi Bali, Jurnal Teknik Sipil UGM 1995

[15] Wardani, Penanggulangan Kecelakaan Lalu Lintas pada ruas jalan kupang- Atambua di Propinsi Nusa Tenggara Timur 1993 Jurnal Teknik Sipil UGM

[16] WHO. 2011. Global Plan fo the Decade of Action for Road Safety 2011-2020. Swiss. 